\title{
Balthasar Hubmaier i njegovih osamnaest teza
}

\author{
Danijel Časni \\ Biblijski institut, Zagreb \\ dcasni@bizg.hr
}

UDK:276:27-722

Pregledni članak

Primljeno: 2, 2018.

Prihvaćeno: 3, 2018.

\section{Sažetak}

U radu se govori o istaknutom anabaptističkom reformatoru Balthasaru Hubmaieru koji je svojim djelima dao značajan doprinos razvoju ranoga anabaptističkog pokreta. 2018. godine se prisjećamo 490. godišnjice njegove smrti spaljivanjem na lomači zbog vjerskih uvjerenja. $U$ radu se predstavlja Hubmaierova biografija i daje pregled njegova stvaralaštva. Posebna pažnja posvećuje se njegovu prvom radu koji sadrži 18 teza, iz lipnja 1524., pod nazivom "Achtzehn schluß rede so betreffende ein gantz Cristlich leben". U tezama je vidljiv Hubmaierov pogled na teologiju, ekleziologiju i pastorologiju na početku njegova reformacijskog djelovanja.

Ključne riječi: Balthasar Hubmaier, anabaptisti, teze, Ulrich Zwingli, reformacija

\section{Uvod}

Balthasar Hubmaier je uz Jeana Calvina, Martina Luthera i Urlicha Zwinglija bio vodeći reformator 16. stoljeća. Podsjetio je na biblijski temelj anabaptističke doktrine o krštenju onih koji vjeruju, odnosno krštenju vjernika na temelju ispovijedi vjere. Odbacio je krštenje dojenčadi, što je bio presedan u kršćanstvu 16. stoljeća. Hubmaier se aktivno zalagao za odvajanje Crkve od države te je odbacio praksu državne crkve, prisutnu u rimokatoličkom i protestantskom kršćanskom svijetu toga vremena. Njegovo prvo djelo iz 1524. nosi naziv Achtzehn schlu $\beta$ rede so betreffende ein gantz Cristlich leben (Osamnaest teza koje se odnose za cjeloku- 
pni kršćanski život). Povod za aktualizaciju Hubmaierova djela je obilježavanje 490 godina od njegove smrti.

\section{Hubmaierova biografija i djela}

Balthasar Hubmaier rođen je u Freidburgu u Njemačkoj, u blizini grada Augsburga. Godina njegova rođenja nije sa sigurnošću determinirana pa se pretpostavlja da je rođen između 1480. i 1485. godine (Bergsten 1978, 48). U članku pod nazivom „Umro je za slobodu vjere“ J. Nordenhaugh $(1969,65)$ navodi 1483 . kao godinu Hubmaierova rođenja.

O Hubmaierovu djetinjstvu postoje oskudni podaci. Potjecao je iz zemljoradničke obitelji. Školovao se u latinskoj školi u Augsburgu za obrazovanje dječaka (Vedder 1905, 26). Nakon što je stekao dobro osnovno obrazovanje, 1. svibnja. 1503. godine upisuje teologiju na Sveučilištu Freidburg u Breisgau, koje je osnovano 1457. godine i jedno je od najstarijih u Njemačkoj. Tijekom studiranja Hubmaieru je ponestalo financijskih sredstava pa je bio prisiljen prekinuti studiranje. Zaposlio se u školi u švicarskome mjestu Schaffhausenu. Kasnije nastavlja svoje školovanje i stječe diplomu prvostupnika teologije 1510. godine. U isto je vrijeme ordiniran za svećenika (Nordenhaugh 1969, 65).

Najvjerojatnije, 1511. godine postiže magisterij (Vedder 1905, 27).

Hubmaierov je mentor na sveučilištu bio Johann Eck. Iako je Hubmaier bio među starijim studentima, to ga nije spriječilo da bude jedan od najboljih. $\mathrm{Na}$ svečanosti prilikom uručenja diplome Eck je hvalio Hubmaiera riječima: „Divno je sjetiti se s kakvom sveobuhvatnošću i ozbiljnošću je svladao filozofske znanosti, kako je netremice slušao svoje učitelje i vrijedno zapisivao predavanja - vrijedni čitatelj, neumorni slušatelj i revnosni pomagač drugim studentima“" (Estep 1986, 47). Johann Eck je kasnije postao vatreni protivnik reformacijskih stavova Martina Luthera. U jesen 1510. godine Johann Eck je otišao sa Sveučilišta Freidburg na Sveučilište Ingolstadt. Hubmaier je slijedio put svoga mentora. U veljači 1512. i Hubmaier stiže na Sveučilište Ingolstadt kako bi nastavio svoje studije. U rujnu iste godine postiže doktorat pa postaje profesorom teologije na Sveučilištu Ingolstadt. Bio je vješt propovjednik i svećenik najveće crkve u gradu (Bergsten 1978, 50), stekao je ugled i postao zamjenik rektora Sveučilišta. Tu je funkciju obnašao do 1515. godine.

Potom 1516. godine napušta Ingolstadt kako bi postao svećenik u katedrali grada Regensburga. U Regensburgu je na temeljima nekadašnje sinagoge, Hubmaier izgradio kapelu „Presvetoj Mariji“ koja je postala mjestom hodočašća (Estep 1986, 49). Bez obzira na situiranost, zahvaljujući milodarima hodočasnika i popularnosti koju je stekao kao vrsni propovjednik, Hubmaier u tome nije našao zadovoljstva pa odlučuje promijeniti sredinu. 
Godine 1521. počinje službu kao župnik crkve u Waldshutu na Rajni, gradu koji se nalazi u blizini granice sa Švicarskom. Vremena u kojima je Hubmaier živio bila su burna jer se iskra reformacije već zapalila diljem Njemačke. Waldshut je bio pod austrijskom upravom, ali zbog blizine granice bio je pod utjecajem reformacijskih strujanja iz Švicarske. Hubmaier je započeo prijateljstvo s humanistom Deziderijem Erazmom Roterdamskim i Johannesom Oecolampadiusom, reformatorom iz Basela. Došavši u kontakt s nekim Lutherovim spisima, Hubmaier je počeo uviđati značaj reformacijske krilatice „Sola scriptura“. U svojim propovijedima sve je više ukazivao na važnost Svetog pisma te je na njemu temeljio svoju teologiju, a svoj je stav dodatno razvio kroz razgovor s Erazmom 1522. godine, koji je kao humanist u svome pristupu imao drugi temelj. ${ }^{1}$

Upravo je utemeljenost u Svetom pismu odredila i oblikovala Hubmaiera kao reformatora. Nije se priklonio ni Lutheru, ni Zwingliju, već je prokrčio put vjerske prakse temeljene isključivo na autoritetu Svetoga pisma, bez utjecaja crkvene tradicije. Tako je Hubmaierova teologija bila neovisna o drugim teolozima (MacGregor 2006, 105).

Početkom 1520-ih godina reformacija je zahvatila mnoge dijelove Europe, tako i područje južne Austrije u kojemu je djelovao Hubmaier. Kao teolog, s potrebnim znanjem i vlastitim stavom našao se u pravo vrijeme na pravome mjestu. Njegove rasprave uvijek su se temeljile na Svetome pismu. Njegova je teološka neovisnost najčešće vodila do sukoba s drugim reformatorima. Kako je udaljenost između gradova Waldshuta i Züricha bila samo $50 \mathrm{~km}$, dvojica reformatora i teologa, Balthasar Hubmaier i Ulrich Zwingli, započela su intenzivne razgovore. Godine 1523. Hubmaier je zajedno sa Zwinglijem započeo raspravu oko prekida prakse krštenja dojenčadi. Sebastian Ruckensperger je izvijestio kako se Hubmör (odnosno Hubmaier) sastao s Zwinglijem u Zürichu, a ovaj mu je tom prilikom dao za pravo, kako je ispravno krstiti djecu tek nakon što bi bili upućeni u vjeru (MacGregor 2006, 107). Tijekom toga vremena Zwingli se usaglasio s Hubmaierom da je krštenje dojenčadi nebiblijsko. Kirk MacGregor (2006, 106-108) tvrdi da je Hubmaier prestao krstiti dojenčad negdje između 1521. i siječnja 1523. godine. Hubmaier nije bio samo teolog već i župnik koji je brinuo o pastoralu svojih župljana. Ako bi roditelji inzistirali na krštenju dojenčadi, on bi ih krstio iako se s time duboko u sebi nije slagao. To je vrijedilo i za slučaj smrtno bolesnog djeteta. Hubmaier piše u pismu svome prijatelju da "ako postoje roditelji bolesnog djeteta, koji bi najviše željeli da im dijete bude kršteno, krstim” (Pipkin i Yoder 1989, 72). Balthasar Hubmaier je jedan od prvih teologa koji je u razdoblju reformacije za-

1 O odnosu Hubmaiera s Erazmom, vidjeti u: Williamson, T. Daren. 2005. Erasmus of Rotterdam's Influence upon Anabaptism: The Case of Balthasar Hubmaier. Doktorski rad. Simon Fraser University. 256 str. 
počeo prakticirati krštenje na temelju vjere. Smatrao je svoje učenje ispravnim, na temelju primjera krštenja iz Svetoga pisma. Hubmaier je izjavio: "Sudite u svojim umovima i savjesti prema jednostavnoj Božjoj riječi. Ali neka sama Riječ Božja bude vaš mirotvorac i sudac. Tada nećete pogriješiti” (Pipkin i Yoder 1989, 99).

Hubmaier se nakon susreta sa Zwinglijem u Zürichu, uputio u svoj grad Waldshut. Tamo su slijedile rasprave oko crkvenih reformi. Waldshutska crkva nije bila pod upravom gradskog vijeća, kakav je slučaj bio u Zürichu. Hubmaier je osobno predvodio crkvene promjene kao „onaj koji propovijeda Božju Riječ i zato može zapovijedati“ (Pipkin i Yoder 1989, 31). Autoritet, koji je imao u društvu, nije iskorištavao da bi se postavio vrhovnim sucem u gradu. Nije autoritativno provodio odluke, već je organizirao rasprave u kojima su sudjelovali svi građani. $\mathrm{Na}$ taj su način građani imali prilike korigirati Hubmaierove stavove.

Kroz crkvenu povijest, Hubmaierov je status bio dvojak. Jedni su ga svrstavali među anabaptiste, dok drugi nisu. Iznenađuje činjenica da je Hubmaier uključen među osnivače anabaptista tek nakon 1944. godine i objavljivanja knjige Harolda S. Bendera Anabaptistička vizija. U napomeni pod brojem 54 Bender zaključuje da Hubmaier predstavlja samo "prolazno odstupanje od izvornog do autentičnog anabaptizma" (Bender 1944, n54).

Normativni ili evanđeoski anabaptizam ${ }^{2}$ zastupali su Conrad Grebel, Felix Mantz i rani pristaše Zwinglija koji su kasnije postali pripadnicima „švicarske braće" (Chatfield 2013, 26). Oni su bili pacifisti. John Howard Yoder je ublažio Benderovu potpuno negativnu procjenu Hubmaiera. Njegova je tvrdnja bila da Hubmaier "nije igrao važnu ulogu" u početku švicarskog anabaptizma jer nije imao veze s Grebelom prije 1523. godine (Yoder 1959, 5). Yoder je tvrdio da Hubmaierova rasprava oko krštenja novorođenčadi "nije bila znak izravnog kontakta između njega i kruga ziriških radikala" (Yoder 1959, 6-7). Rudolph Henry Wiens je u svojem magistarskom radu napomenuo kako...

„... slika Balthasara Hubmaiera, bavarskoga anabaptističkog vođe, koji je živio od otprilike 1480. do 1528. godine, a koje proizlazi iz nedavnih istraživanja početaka anabaptizma, takva je da bi pribjegao nasilju u obrani svojih stavova, slično švicarskom reformatoru Zwingliju, a u suprotnosti sa stavovima švicarske braće, koji su postali prvi anabaptisti. Ovakva je slika prisutna već dugo, no u novije su je doba podupirali znanstvenici poput Horscha, Bendera, Bergstena, i Stayera (...) Bez obzira na to je li takav stav pravičan ili nije, rezultirao je rasprostranjenim ignoriranjem nekih od najboljih radova ranoga anabaptističkog stvaralaštva, kao što je njegova Suma cijeloga kršćanskog života, koja zaslužuje biti prepoznata kao klasik za sva vremena“ (Wiens 2010,1).

2 Više o ranom anabaptizmu u: Gonzales Lucic, Antonia. 2011. Balthasar Hubmaier and early Christian tradition. Proquest, Umi Dissertation Publishing. 
Arnold Snyder, jedan od najvećih povjesničara i istraživača anabaptizma, napomenuo je kako „unatoč tomu što su prvi vođe bili Conrad Grebel, Felix Mantz i Georg Blaurock, nijedan od njih nije napisao ili objavio značajna djela u obranu krštenja odraslih. Taj je zadatak pao na Balthasara Hubmaiera, jednog od ranih anabaptističkih vođa iznimnog značaja" (Snyder 2009, 80). U napomeni pod brojem 13 Snyder je dodao kako:

„Hubmaier je neopravdano marginaliziran u menonitskim povijestima prije svega zato što nije bio pacifist. Neobično je što su povjesničari poligeneze, koji se po pravilu usredotočuju na 'mač kao na središnju temu, također skloni marginalizirati Hubmaiera kao „netipičnog" anabaptista. Ustvari, Hubmaier je vjerojatno pridonio definiranju rane teološke jezgre anabaptističkog nauka više nego itko drugi. Švicarska su braća doslovno citirala njegove spise o krštenju još u sedamnaestom stoljeću“" (Snyder 2009, 90).

Proučavajući Hubmaierov život, njegovo djelovanje i pisana djela, uvažavam mišljenje povjesničara Snydera. Stoga, priklonit ću se njegovoj interpretaciji ovoga velikog reformatora i utemeljitelja ranoga anabaptističkog pokreta.

Biblija je za Hubmaiera bila temelj na kojemu je gradio svoju interpretaciju krštenja vjernika, a protiv krštenja dojenčadi. Praksa paedobaptizma seže u ranu povijest Crkve 3. stoljeća, zbog roditeljske brige za spasenje dojenčadi (McGreath 2001, 528). Hubmaier je iznio argument da čin krštenja treba slijediti vjeru kao rezultat biblijskog učenja. Bez vjere, krštenje nema smisla. Stoga, Hubmaier se pozvao na biblijski redak u Mk 16,15-16, gdje Isus zapovijeda svojim učenicima: "Idite po svem svijetu i propovijedajte Radosnu vijest svakom stvorenju! Tko bude vjerovao i pokrstio se, spasit će se; tko ne bude vjerovao, osudit će se." Sukladno navedenom tekstu, Hubmaier ističe važnost triju Kristovih zapovijedi: propovijedanje, vjerovanje i krštenje. Iz navedenoga slijedi kako krštenju prethodi slušanje Riječi Božje i njezino prihvaćenje vjerom (Pipkin i Yoder 1989, 115).

Krštenje predstavlja i čin inicijacije u Kristovo tijelo - njegovu Crkvu, kao vidljiv eklezijalni element Kristove prisutnosti u svijetu. Hubmaier piše: "Mora postojati vanjska ispovijed ili svjedočanstvo kroz koje se vidljiva braća i sestre mogu upoznati jedni s drugima jer vjera postoji samo u srcu" (Pipkin i Yoder $1989,127)$. Osim što je krštenje svjedočanstvo, ono i obvezuje te potiče na odgovorno ponašanje vjernika, kako u Crkvi tako i u društvu. Osim što simbolizira prelazak iz smrti u novi život s Kristom, krštenje je čin dobrodošlice u lokalnu zajednicu vjernika. Hubmaier je napisao: "Ali kad prima krštenje vode, onaj koji je kršten, javno svjedoči kako se sam obvezao živjeti u skladu s Kristovim zapovijedima. Zahvaljujući ovom zalogu, predao se sestrama, braći i crkvi tako da ga u prekršaju imaju ovlasti opominjati, kažnjavati, zabranjivati i ponovno prihvatiti“"(Pipkin i Yoder 1989, 127). Važno je naglasiti kako Hubmaier ističe spasenje 
jedino po vjeri, a ne po krštenju. S obzirom na to da je krštenje zapovjedio sam Krist, ono prestaje biti opcija, a postaje obveza. Hubmaier je rekao da "tko vjeruje, neka se krsti i ne nastavlja raspravljati, jer gdje se nalazi voda i osoba koja ga može krstiti, pred njegovim očima je Kristov red. Međutim, ako je voda ili osoba nedostupna, njihova je vjera dovoljna" (Pipkin i Yoder 1989, 124). U primjeru razbojnika na križu nije bilo moguće krštenje pa ipak mu je Krist rekao kako će biti s njime u raju. Stoga, Hubmaier napominje da svi koji imaju prilike, neka se krste kako ne bi bili osuđeni zbog Kristovih riječi te zbog toga bili kažnjeni (Pipkin i Yoder 1989, 140).

Krajem 1523. godine teologija svećenika iz Waldshuta naišla je na otpor kod rimokatoličkih predstavnika grada Ensisheima u Austriji. Došavši u Waldshut, podigli su tri tužbe protiv Hubmaiera u kojima ga osuđuju da se pridružio "Lutherovom novovjerstvu“, da je bio predstavnik nekoliko gradova na drugoj raspravi u Zürichu sa Zwinglijem te da je pogrešno tumačio Sveto pismo u svojim propovijedima. Delegacija grada Ensisheima željela je uhititi svećenika i predati ga biskupu iz Konstance. Međutim, Gradsko vijeće nije željelo izručiti Hubmaiera te ga je svesrdno branilo. Naposljetku, izaslanstvo je dalo rok od četrdeset dana za ispunjenje njihovih zahtjeva. Već tjedan dana kasnije, Gradsko je vijeće Waldshuta napisalo službenom izaslanstvu odgovor da je Hubmaier nevin. To je bio poziv na djelovanje austrijske kraljevske vojske. Već su te zime trebali doći u Waldshut i privesti Hubmaiera. No zbog rata u Francuskoj, vojska nije mogla odmah reagirati. Takva latentna opasnost nije spriječila Hubmaiera da bude aktivan u svome pastoralnom radu. Stoga, 11. siječnja 1524. šalje „Poziv braći“ da se u njegovoj kući okupe svi sa svojim Biblijama kako bi proučavali Božju Riječ. Na sastancima su raspravljali o vjerskim pitanjima i razvijali zajedništvo uz ohrabrenje iz Svetoga pisma (Broadbent 1989, 156). To je bila priprema za kasnije rasprave oko osamnaest teza koje će biti tiskane u slijedeća tri mjeseca.

U srpnju 1524. austrijska je vlada pozvala svoje vojne postrojbe iz Innsbrucka da napadnu grad Waldshut, što je podržao i sam Ferdinand I., kralj svetog Rimskog Carstva. Zbog dobre organizacije i pripremljene obrane sačinjene od seljaka i građana grada Waldshuta s okolicom, napad je odgođen. Kako bi spriječio krvoproliće, Hubmaier je napustio Waldshut i sklonio se u švicarski grad Schaffhausen, gdje je boravio još kao student. Tamo je nastavio pisati svoja djela. Do kraja 1524. godine napisao je tri djela: Eine ernstliche christliche Erbietung (Jedna ozbiljna kršćanska žalba), Axiomata - Schlussreden gegen Eck (Axiomatateze protiv Ecka) $i$ Von Ketzern und ihren Verbrennern (O hereticima i njihovim spaljivateljima). Želja mu je bila potaknuti raspravu o otvorenim pitanjima, a bio je spreman prihvatiti i drukčija mišljenja, što nije bila odlika tadašnjih vjerskih lidera. Svoje važno djelo Von Ketzern und ihren Verbrennern u 36 članaka posvetio 
je Anthonyju, vikaru u Konstanzi, navodeći da je istina nevidljiva i da su heretici svi oni koji se suprotstavljaju Svetom pismu. Opominje Anthonyja kako se treba kloniti svoga krivovjerstva i pristajanja uz Papu. Važno je primijetiti da je u tom trenutku prošlo već 109 godina od spaljivanja mučenika Jana Husa na Koncilu u istome gradu. On je bio veliki borac za istinu do same smrti. Stoga, Hubmaierove su riječi bile podsjetnik, ali i opomena, s obzirom na aktualna zbivanja toga vremena. Iako je tvrdio da postoje heretici, smatrao je da ih treba nježno upućivati na ispravan put. Hubmaier je smatrao u svjetlu Božje riječi iz Matejeva evanđelja, 13. poglavlja, kako pšenica treba rasti zajedno s kukoljem. Spaljivanjem kukolja ne slijedi se Kristov primjer i samim time, oni koji spaljuju, postaju heretici. Žele odvojiti pšenicu od kukolja prije vremena, za što nemaju poslanje. Kršćani su pozvani boriti se protiv bezbožnika mačem, ali taj mač nije metalno oružje, već Riječ Božja. Svjetovne su vlasti pozvane kažnjavati zle ljude za svjetovne prekršaje, ali ne heretike niti krivovjerce. Hubmaier je smatrao kako će hereticima suditi Bog.

Nakon što se situacija u Waldshutu smirila, Hubmaier je krenuo na put. U jesen 1524. na povratku kući iz Schaffhausena u Waldshut, zaustavio se u Zürichu kod Zwinglija. Građani su mu priredili veliku dobrodošlicu i tom su prilikom bacali svoje crkvene slike i kipove. Ohrabren ovim činom, Hubmaier je počeo ponovno neustrašivo propovijedati u Waldshutu.

Kako se nije slagao s crkvenim stavom o celibatu, 13. siječnja 1525. Hubmaier se oženio za Elizabeth Hugline, što je podržao cijeli grad, a za taj čin pozvao se na svoje prvo djelo. Elizabeth je bila posvećena svome mužu Balthasaru i reformi koju je pokrenuo. Vjerno ga je pratila i podržavala. Kada su nastupili progoni, bježala je zajedno s njim. Na kraju ga je vjerno pratila do same smrti.

Tri mjeseca nakon vjenčanja slijedio je važan događaj u životu reformatora koji je označio službeni ulazak Hubmaiera u anabaptističku tradiciju u travnju 1525. Tada je u Waldshut stigao Wilhelm Reublin, anabaptistički propovjednik koji je bio protjeran iz Züricha zbog propovijedanja protiv biskupskog uređenja grada. On je podržavao krštenje na osnovu osobne vjere te je 14. travnja 1525. krstio Hubmaiera i ostale članove svećenstva. Njih oko šezdesetoro. Slijedilo je krštenje oko 300 vjernika od strane Hubmaiera (Broadbent 1989, 158).

Iste je godine, među ostalim, objavio dva vrlo značajna anabaptistička djela: Eine Summe eines ganzen christlichen Lebens (Suma cjelokupnog kršćanskog života) te Von der christlichen Taufe der Gläubigen (Od kršćanskog krštenja vjernika). Prvo djelo iz srpnja 1525. posvećeno je trima gradovima u kojima je Hubmaier živio, a u kojima se odvijala loša kršćanska praksa. Riječ je o Friedbergu, Ingolstadtu i Regensburgu. U njemu u pet točaka sažima cjelokupni kršćanski život. Drugi rad govori o krštenju, i to je vjerojatno najviše proučavano Hubmaierovo djelo. Ono je refleksija Zwinglijeva stava o krštenju, ponovnom krštenju i kršte- 
nju dojenčadi iz svibnja 1525. Taj opsežan rad sadrži sedam poglavlja. Ovim je djelom prouzročio žustre rasprave sa Zwinglijem i Calvinom. Hubmaier je pokazao kako u Novom zavjetu ne nalazi krštenje dojenčadi i da se krštavaju samo oni koji vjeruju. Iznosi analogiju da Božja Riječ prvo treba biti propovijedana, nakon čega slijedi slušanje. Potom je prihvaćena i rezultira promjenom u srcu vjernika. $\mathrm{Na}$ kraju, slijedi pokajanje za grijehe koje rezultira vjerom. Krštenje nastupa kao rezultat vidljive vjere. Zwingli je iste godine napisao svoju raspravu kao odgovor na Hubmaierovo promišljanje.

Kako se austrijska vojska približila gradu Waldshutu, on je 5. prosinca 1525. pobjegao sa suprugom u obližnji Zürich. Saznavši da je u gradu, Zwingli ga je dao uhititi. Sazvana je sjednica kako bi se ispitala Hubmaierova uvjerenja. Trebao se javno odreći svojih stavova. No, umjesto da ih javno ospori u Fraumunsterskoj crkvi, odlučno ih je branio. Posebno je branio svoj stav oko krštenja. Odmah je priveden i mučen sedam mjeseci.

Nakon puštanja iz Züricha, Hubmaier je otišao u grad Nikolsburg u lipnju ili srpnju 1526. godine (Graffagnino 2017, 13). Ovaj je grad bio religiozno tolerantan i dopuštao je djelovanje reformatora. Anabaptistička reformacija brzo je rasla u Nikolsburgu. Procjenjuje se da je Hubmaier krstio najmanje šest tisuća ljudi tijekom kratkog vremena u gradu (Estep 1986, 59), dok neki autori govore o dvostruko većem broju (Nordenhaugh 1969, 66).

Nikolsburg je bio pod upravom baruna Leonarda von Liechtensteina koji je iz Züricha pozvao tiskara Simprechta Sorga. Njegov je zadatak bio osnovati tiskaru u Nikolsburgu i nastaviti tiskati Hubmaierova djela. Die zwölf Artikel des christlichen Glaubens (Dvanaest članaka kršćanske vjere) i Ein kurzes Vaterunser (Kratka molitva Očenaš) prva su djela tiskana u Nikolasburgu na osnovu Hubmaierovih rukopisa iz zatvora u Zürichu. U Dvanaest članaka kršćanske vjere definirao je osnove kršćanskog vjerovanja temeljene na apostolskom vjerovanju. $U$ Kratkoj molitvi očenaš, nalaze se promišljanja o molitvi Gospodnjoj iz Matejeva evanđelja. U djelu Der uralten und gar neuen Lehrer Urteil (Stara i nova procjena učitelja) iznosi se prosudba starih i novih učitelja u kojemu se navode stavovi crkvenih otaca, Origena, Autanazija, Tertulijana i Jeronima po pitanju krštenja dojenčadi (Estep 1986, 56). Njihove stavove Hubmaier komparira sa stavovima svojih suvremenika, poput njemačkih reformatora Martina Luthera, Johannesa Oecolampadiusa i Wolfganga Capita, te švicarskih reformatora Ulricha Zwinglija i Lea Juda.

S obzirom na to da je barun Leonard von Liechtenstein prepoznao Hubmaierov stvaralački talent te mu osigurao potrebnu tehničku i financijsku podršku, Hubmaier se mogao posvetiti pisanju. U sljedeće dvije godine, između 1526.1528., tiskano je 17 njegovih djela. 
Hubmaierova djela ${ }^{3}$ postala su karakteristična po tome što su sva temeljena na Bibliji. Važno ih je promatrati kao zbirku djela o velikim reformacijskim temama, kao što je krštenje, crkva, slobodna volja, Gospodnja večera, krivovjerje i odnos prema državi. Cjelokupan popis može nam dati uvid u žar za pisanom riječi koju je ovaj reformator ostavio u nasljedstvo. Stoga, donosim popis njegovih djela na izvornom njemačkom jeziku, s godinom izdanja.

1. Achtzehn Schlussreden (1524.)

2. Eine ernstliche christliche Erbietung (1524.)

3. Axiomata - Schlussreden gegen Eck (1524.)

4. Von Ketzern und ihren Verbrennern (1524.)

5. Etliche Schlussreden vom Unterricht der Messe (1525.)

6. Öffentliche Erbietung (1525.)

7. Eine Summe eines ganzen christlichen Lebens (1525.)

8. Von der christlichen Taufe der Gläubigen (1525.)

9. Ein Gespräch auf Zwinglis Taufbüchlein (1525.-1526.)

10. Die zwölf Artikel des christlichen Glaubens (1526.-1527.)

11. Ein kurzes Vaterunser (1526.)

12. Der uralten und gar neuen Lehrer Urteil (1525.-1526.)

13. Von der Kindertaufe (1526.-1526.)

14. Eine kurze Entschuldigung (1526.)

15. Ein einfältiger Unterricht (1526.)

16. Eine christliche Lehrtafel (1526.-1527.)

17. Grund und Ursache (1526.-1527.)

18. Von der brüderlichen Strafe (1526.-1527.)

19. Eine Form zu taufen (1526.-1527.)

20. Eine Form des Nachtmahls Christi (1526.-1527.)

21. Von dem christlichen Bann (1526.-1527.)

22. Von der Freiheit des Willens (1527.)

23. Das andere Büchlein von der Freiwilligkeit des Menschen (1527.)

24. Von dem Schwert (1527.)

25. Eine Rechenschaft des Glaubens (1528.)

Hubmaierovi spisi i knjige širile su se diljem Europe. Hubmaierov oštri progonitelj, vladar svetog Rimskog Carstva Ferdinad I., bio je 1526. okrunjen za kralja Bohemije i Ugarske, a već sljedeće 1527., postao je kraljem Hrvatske. Kako je bio vatreni progonitelj anabaptista na teritoriju gdje je vladao, spriječio je širenje radikalnih reformacijskih pokreta. Možda je to razlog što je utjecaj anabaptistič-

3 Cjelokupni popis Hubmaierovih djela dali su autori Westin, Gunnar i Bergsten, Torsten u radu: Quellen zur Geschichte der Täufer IX, Hubmaier, Balthasar: Schriften, Quellen und Forschungen zur Reformationsgeschichte, Gütersloh, 1962. 
kih pokreta u hrvatskim zemljama bio vrlo ograničen. Kao dijagnozu tadašnjeg stanja, govori izvještaj Stanka Jambreka:

„Rani anabaptistički vođe bili su progonjeni od svih: vlasti, rimokatolika, luterana i kalvina. Većina je njih, posebice u Austriji i austrijskim nasljednim zemljama, nakon obraćenja Bogu preživjela samo nekoliko godina, i to u bijegu. Zbog nemilosrdnog progona, jakih protureformacijskih mjera i aktivnosti te neprestane borbe s osmanlijama, anabaptistička tradicija reformacije nije se raširila ni utvrdila u hrvatskim povijesnim zemljama“"(Jambrek 2011, 342).

Kralj Ferdinand I. prisilio je baruna Leonarda von Liechtensteina da poštuje odluku Karla V. Habsburškog od 26. svibnja 1521. pod nazivom Wormski edikt, kao kazne progona svih „novovjeraca“. 28. kolovoza 1527. godine Liechtenstein je Balthasara Hubmaiera i njegovu suprugu izručio na saslušanje koje se održalo u Beču. Nakon saslušanja, zatočili su ih u dvorcu Kreuzenstein u blizini Beča.

Tamo je Hubmaier napisao svoje posljednje djelo Eine Rechenschaft des Glaubens (Obračun svoga vjerovanja) kralju Ferdinandu I., u nadi da će ga pročitati i poštedjeti mu život. Međutim, reakcija kralja je izostala (Estep 1986, 62).

Nakon sedam mjeseci, 3. ožujka ponovno je pozvan u Beč. Uslijedila su mučenja koja su trajala sedam dana. Cilj je bio slomiti Hubmaiera i prisiliti ga da odbaci svoje stavove. Međutim, on se nije pokolebao i ostao je čvrst. Desetog su ožujka egzekutori krenuli zajedno s njegovom suprugom na gubilište do lomače. Hubmaierova supruga ga je cijelo vrijeme ohrabrivala da ustraje i ostane vjeran. Molio je braću da mole za njega kako bi imao strpljenja u patnji. Stigavši do lomače, skinuli su s njega odjeću i zapalili plamen. Njegove su posljednje riječi bile: „O Gospode, i s tebe su skidali plašt. Rado ću ostaviti svoje odijelo. Sačuvaj samo moj duh i moju dušu, molim te! (...) O draga braćo, molim se Bogu da mi oprosti moju krivicu u ovoj smrti. Želim da umrem u kršćanskoj vjeri" dok mu je bradu i kosu hvatao plamen, uzviknuo je: O Isuse, Isuse i umro je gušeći se u dimu (Estep 1986, 63). Njegov su pepeo bacili u Dunav, kako njegovi sljedbenici ne bi mogli obilaziti njegov grob.

Tri dana kasnije Hubmaierovoj supruzi Elizabeti vezali su kamen oko vrata i bacili je u rijeku Dunav gdje se utopila. Bila je to uobičajena kazna koja je primjenjivana za anabaptiste, odnosno „nanove krštenike“ i od strane katolika i protestanata. Taj čin umorstva pogrdno su nazivali „treće krštenje“.

\section{Osamnaest Hubmaierovih teza}

U travnju 1524. je Hubmaier organizirao raspravu u Waldshutu, a tom je prilikom predstavio svoje prvo djelo pod nazivom Achtzehn schluß rede so betreffende ein gantz Cristlich leben, waran es gelegen ist. (Osamnaest teza o cjelokupnom kr- 
Preslik naslovnice Hubmaierovih teza. Djelo je izdao Ramminger 1524. godine, a čuva se u Staats- und Stadtbibliothek Augsburg. Izvor: https://books.google.hr/intl/ hr/googlebooks/tos.html

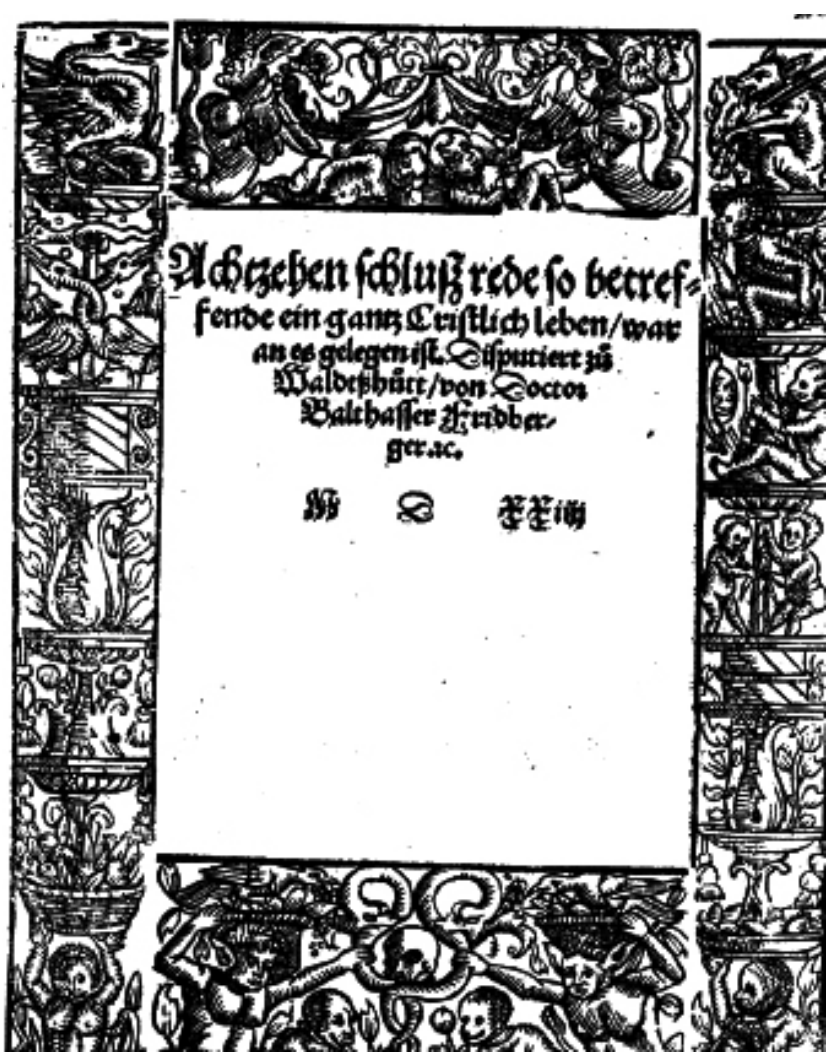

šćanskom životu i od čega se sastoje). ${ }^{4} \mathrm{U}$ njemu se u osamnaest članaka govori o cjelokupnom kršćanskom životu. Teze prikazuju Hubmaierovu teologiju, osnove njegove ekleziologije i pastoralne prakse za vjernike Waldshutske crkve. Knjižicu, opsega 8 stranica, objavio je Ramminger 1524. godine, a čuva se u Sttats und Stadtbibliothek u Augsburgu. Njezin je sadržaj bio osnova za kasnije rasprave s ciljem reforme Crkve koja je uslijedila. Slične su se rasprave događale diljem reformacijskih središta. U Zürichu su takve rasprave poticali autoriteti gradskog Vijeća, kao izvršnog tijela za pravna pitanja, diskusije i primjenu zaključaka. U Waldshutu su rasprave bile dijelom redovitih crkvenih službi koje je predvodio Hubmaier smatrajući da zapovijedati može samo onaj koji propovijeda Riječ Božju (Pipkin i Yoder 1989, 31). Smatrao je da gradska vlast nema pravo sudjelovanja u raspra-

4 Prijepis originala: Glaubensstimme-Das evangelische Arhiv im Internet, Schlussreden, http:// glaubensstimme.de/doku.php?id=autoren:h:hubmaier:schlussreden. (pristupljeno 15. 2. 2018.). 


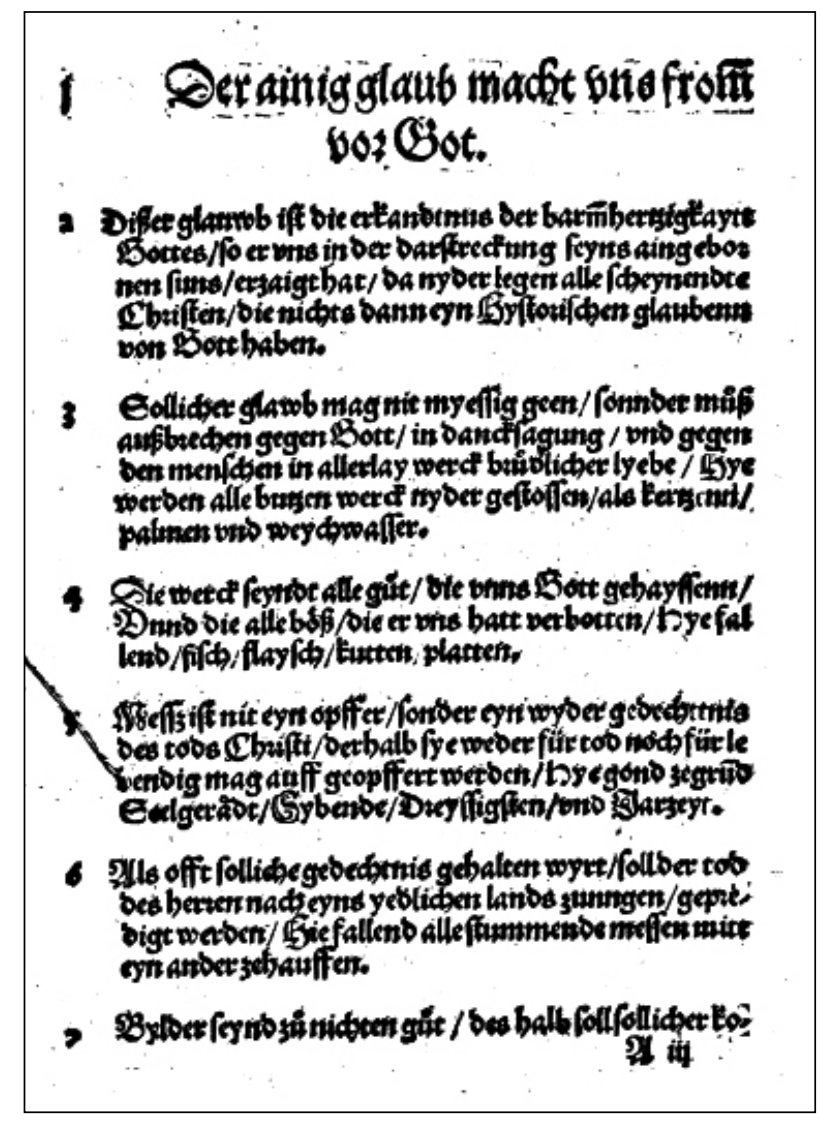

Preslik teza

vama ili primjeni donesenih crkvenih stavova. Osamnaest teza bio je svojevrsni uvodnik u anabaptističke teološke rasprave o kojima će Hubmaier progovarati kroz druga djela u sljedećih tri godine. Temelj cijele njegove teologije, kao i ove knjižice, počiva na „pisanoj Božjoj Riječi“ na koju poziva svoje vjernike.

TEZE (Vedder 1905, 69-71):

1. Vjera nas opravdava pred Bogom.

2. Vjera je razumijevanje Božje milosti, koja se manifestira darivanjem njegova jedinoga rođenog Sina. Ovo isključuje sav sram nazovi kršćana, koji imaju samo „povijesnu vjeru“ u Boga.

3. Vjera ne može ostati mrtva, već se mora manifestirati u samoj sebi u zahvalnosti Bogu, prema bližnjima u djelima bratske ljubavi. Time su sve ceremonije odbačene, pokora, paljenje svijeća ili korištenje pomasti i sveta voda. 
4. Samo su ona djela dobra koja je Bog zapovjedio i samo ona su zla koja je On zabranio. Time pada riba, meso, tonzura, kapuljača i pladanj.

5. Misa nije žrtvovanje, nego sjećanje na smrt Gospodnju. Stoga, nije žrtva ni za mrtve ni za žive. Tako moraju propasti duše onih koji sude i lažu.

6. Kada se slavi ta ceremonija, smrt Gospodinova treba se propovijedati na materinjem jeziku vjernika. Time padaju sve tihe mise.

7. Slike i kipovi nisu dobre nizašto. Zbog toga takav trošak više ne bi trebao bio potraćen na slike od drva ili kamena, nego darivati živuće, slike Božje u potrebi.

8. Svaki kršćanin treba vjerovati i biti kršten za sebe osobno te je njegova privilegija prosuđivati na osnovu Svetoga pisma jesu li mu kruh i vino ispravno dati od strane svećenika.

9. Kao što je Krist sam umro za naše grijehe, i mi smo sami kršteni u njegovo ime, stoga ne možemo ispred njega imati zagovornika ili posrednika. Tako padaju sva hodočašća.

10. Bolje je objasniti jedan redak psalma u narječju naroda nego pjevati pet cijelih psalama na stranom jeziku, koji je narodu nerazumljiv. Time nestaju polnoćke, zornice, poslijepodnevna trica, prijepodnevna devetnica, podnevna služba, ponoćna služba, noćne molitve.

11. Sve doktrine, koje nisu utemeljene na samome Bogu, beskorisne su, zabranjene i trebaju biti iskorijenjene. Ovdje prizemljujemo Aristotela, skolastike kao Tome, Scota, Bonaventure i Occama, te sve učitelje koji nemaju svoju ukorijenjenost u Bogu

12. Dolazi vrijeme i već je tu, u kojemu se nitko neće opravdati propovjednikom, već propovijedanjem Riječi Božje. Time padaju govori o ranim misama, pokore, mise za mrtve, govori o misi zadušnici.

13. Dužnost je članova Crkve da, kada im je propovijedana čista Riječ Božja, osiguraju hranu i odjeću za službenike. Time padaju na zemlju porotnici, umirovljenici, posrednici, odsutni, lažljivci i brbljivci snova.

14. Oni, koji traže čistilište, vjeruju u one čije dobro je njihov trbuh, traže grob Mojsija, koji nikada neće pronaći.

15. Zabrana ženidbe svećenicima i smijuljenje njihovoj raspuštenosti i bijedi isto je kao da oslobodimo Barabu i ubijemo Krista.

16. Držanje obećanja čistoće u ljudskoj snazi, nije ništa drugo nego letjeti preko mora bez krila.

17. Onaj koji radi svjetskog probitka potiče šutnju ili prešućuje Riječ Božju, prodaje Božju milost, kao što je riđokosi Ezav prodao svoje prvorodstvo, te će svi takvi od Krista biti odbijeni.

18. Svaki onaj koji ne zasluži svoj kruh u znoju lica svog već je pod osudom 
i nije dostojan hrane koju jede. Ovdje su date sve moguće osude.

Na početku knjižice Hubmaier se obraća svojem čitateljstvu riječima: „Ja Balhtasar Fridberški doktor i pastor u Waldshutu, želim milost i mir u Kristu Isusu, Gospodinu našemu, svoj braći svećenicima kao i kapelanu“ (Estep 1986, 225)

U uvodnim riječima pozdrava Hubmaier se obraća imenom Batlhasar Fridberški jer je u tome periodu vjerojatno bio poznatiji po mjestu svoga rođenja nego po svome prezimenu. U kasnijim djelima predstavljao se je kao: Balthasar Hubmör iz Fridberga. Nakon uvodnih riječi, slijedi predgovor.

„Ljubljeni ljudi i braćo, drevni je običaj, još iz apostolskih vremena, da kada se sruče zle sile koje se odnose na vjerovanje, svi ljudi koji žele govoriti Božju Riječ i svi koji razmišljaju na kršćanski način trebaju se okupiti u proučavanju Pisma. To se radi kako bi se briga o kršćanskom stadu, u skladu s Božjom Riječi, vodila s najvećom brižnošću. Takav skup naziva se sinodom, saborom ili bratstvom. Ovakvi sabori mogu, naročito u ova opasna vremena, našim vjernicima pružiti čast i dobru volju u izobilju. Trebamo hraniti ne samo svoja tjelesa jelom i pićem, već i njegovati svoje duše da budemo korisniji svome stadu i napajati ga Božjom Riječju u miru i jedinstvu. Zbog ovog cilja treba ukloniti sve uvredljive i svadljive riječi. Zato vas savjetujem, ljudi i braćo, da zbog zajedništva u bratskoj ljubavi, zbog svetosti kršćanskog mira i zbog imena Gospodina našega, Isusa Krista, kroz ove disertacije, koje sam napisao u obliku pitanja i istraživanja, steknete biblijsku osnovu, kako biste na sljedećem sastanku sabora, koji će se održati u Waldshutu, mogli mirno i bratski sa mnom porazgovarati. Sada, da ne bismo nepotrebno gubili vrijeme ljudskim ispraznostima, a time povrijedili i osobni dobar glas, donesite svoje Biblije ili, ako ih nemate, svoje misale, kako bismo jedan s drugim u potpunosti podijelili Bogom dane riječi kršćanske pouke. Što se mene tiče, učinit ću sve što je u mojoj moći da s ovog bratskog objeda ne odete kući nenahranjeni duhovnom hranom i nenapojeni duhovnim pićem. Pozdravljam vas u ime Isusa Krista, Spasitelja našega" (Estep 1986, 225).

Ovaj je predgovor ujedno bio i najava rasprave koja je uslijedila u Waldshutu, a koja je bila osnova za reformu Crkve i cijeloga grada Waldshuta. Nakon predgovora u knjižici, slijedi niz od osamnaest teza.

Graeme Chatfield $(1993,57)$ u studiji razvoja reformacijskih hermeneutičara „Balthasar Hubmaier and the clarity of Scripture” primjećuje kako se u tezama ne poziva izravno na biblijski tekst. Ta je činjenica indikativna s obzirom na to da je Sveto pismo bilo osnova Hubmaierova vjerovanja. No, iako se ne citira svetopisamski tekst, postoje indirektne asocijacije na četiri starozavjetna i deset novozavjetnih tekstova u djelu Osamnaest teza.

Da je vjera temelj odnosa vjernika s Bogom, govore prve tri Hubmaierove teze. Samo vjerom opravdani smo pred Bogom, na temelju milosti Božje koja nam je darivana kroz Krista. To je poziv na odbacivanje tradicije i „vjere otaca“ 
te prihvaćanje životvorne vjere koja čini promjenu u životu vjernika. Takva vjera ne može ostati sama, već se manifestira u zahvalnosti prema Bogu i u ljubavi prema bližnjem. O Hubmaierovu stavu o njegovoj doktrini opravdanja vjerom može se više istražiti u radu Michaela Whitlocka $(2014,147)$ pod nazivom Balthasar Hubmaier's Doctrine of Justification. U tezama se primjećuje otklon od dotadašnje crkvene prakse i tradicije. Tako, za Hubmaiera paljenje svijeća, slike, kipovi i sveta voda u crkvi nemaju nikakve koristi.

U 4. tezi govori se o karakteru djela. Samo ona djela koja je Bog zapovjedio su dobra. S druge strane, loša su ona koje je zabranio. Time dolazi do gubitka značaja pojedinih crkvenih elemenata, poput objeda ribe, mesa, tonzure, kapuljače i pladnja jer one nisu zapovjeđene. Hubmaier, identificira biblijske retke iz Mt 15,13; Mt 19,17 te Pnz 12,32. kako bi definirao da su samo one stvari dobre koje je zapovjedio Bog. Načelno, zapovijedi vode dobrome, a zabrane sprečavaju zlo. Razumijevanje Hubmaierove antropologije je ključ razumijevanja njegove soteriologije (Eaton 2010, 68). Spasenje je temeljeno na Riječi. U Bibliji se ne nalazi zapis o tjednom striktnom objedovanju ribe i nemrsa. Isto tako tonzura ili podstrig bilo je karakteristično šišanje svećeničke glave i znak ulaska u kler. Habit sa kapucom bilo je uobičajeno svećeničko odijelo, no o njima nema zapisa u Bibliji. Riječ Blatten moguće je prevoditi s lišće ili tanjur. Vjerojatno je riječ o nekom sakramentalnom predmetu u sklopu mise, poput okovratnika ili štole, koja se stavljala na svećeničko ruho.

U 5. tezi donosi se Hubmaierov pogled na Večeru Gospodnju koja za njega nije žrtvovanje, već prisjećanje na Kristovu žrtvu i smrt. Stav oko krštenja bila je važna odrednica pokreta švicarske braće, što je bilo vidljivo i kroz rasprave sa Zwinglijem. Hubmaieru je primarni izvor za pisanje teza bila pisana Riječ Božja koja je ujedno bila izvorom za sva pitanja i otkrivenje Božje volje. Za Zwinglija je pisana riječ bila interpretacija uredbi Duha Svetoga, prema kojoj vjernik unutar sebe doživljava Evanđelje, tako da prosuđuje volju Božju (Chatfield 1993, 56).

U 6. tezi govori se o liturgijskom bogoštovlju. Kada se slavi crkvena ceremonija, smrt Gospodinova se treba propovijedati na materinjem jeziku vjernika. Time padaju, odnosno gube na značaju tihe mise (lat. Missa Lecta). Uvođenje narodnog jezika u liturgiju bilo je obilježje svih reformatora, a jačalo je nacionalni identitet i razvoj opće pismenosti vjernika.

U 7. tezi govori se o unutarnjem uređenju crkvenih građevina. Odbacujući čudotvornost slika i kipova, Hubmaier ih smatra samo troškom. Ne samo za njihovo postavljenje, već i za održavanje. S druge strane, sredstva bi se mogla korisnije upotrijebiti za zbrinjavanje i pomoć potrebitih, čime se pokazuje ljubav Kristova na djelu.

U 8. tezi Hubmaier kaže da svaki kršćanin treba osobno vjerovati i biti kršten osobno za sebe. Nitko ne može to učiniti umjesto nekoga. Vjernik ima privilegij 
prosuđivati. Na neki način, već se u ovom članku iščitava stav Hubmaiera o krštenju i autoritetu. Jasno daje do znanja kako vjera prethodi krštenju, a da je apsolutni autoritet za kršćanski život Riječ Božja. Na osnovu nje, svaki vjernik ima privilegiju prosuđivati je li duhovna hrana koju prima u crkvi od svojih pastira ispravna ili nije. Stoga, autoritet je svećenika podređen autoritetu Svetog pisma, a svaki je vjernik u zajednici pozvan prosuđivati svećeničku poruku u svjetlu Božje Riječi.

U 9. tezi govori o zagovoru. Krist je sam umro za grijehe cijeloga čovječanstva. Nije to učinio s nekim svecima ili zaštitnicima po čijem su se zagovoru vjernici utjecali Kristu u pomoć. Kao što je Krist umro za grijehe, i svaki vjernik mora biti kršten u njegovo ime, za što nije potreban posrednik. Hubmaier ističe da time padaju sva hodočašća.

U 10. tezi Hubmaier ističe važnost čitanja Svetoga pisma na narodnom jeziku. Narod mora razumjeti ono što mu se govori te kaže kako je vrjednije objasniti jedan redak psalma u narječju naroda nego pjevati pet cijelih psalma na jeziku koji narod ne razumije. S obzirom na tadašnju crkvenu praksu i upotrebu latinskog jezika u liturgiji, različita crkvena bogoštovlja izgubila su smisao ako vjernicima nisu razumljiva.

U 11. tezi Hubmaier ponovno ponavlja važnost utemeljenja svoga vjerovanja u Bogu. U Mateju 15,13 piše „iščupat će se svaka sadnica koju nije zasadio moj nebeski Otac". Kako je to bilo vrijeme razvoja humanističkih učenja, koja nisu temeljena na Riječi Božjoj, Hubmaier smatra da su ona beskorisna te poimence nabraja filozofe i mislioce čija uvjerenja kategorički odbija.

U 12. tezi govori o tome da Krista treba staviti u središte bogoštovlja, a ne da na tome mjestu sjedi propovjednik. Opravdanje se nalazi u Riječi Božjoj, a ne u zagovorima propovjednika. Stoga, svećenik gubi autoritet kao onaj koji odlučuje i određuje pokoru, sudbinu duše ili mrtvih. Hubmaier ponovno upućuje na autoritet Svetog pisma

U 13. tezi Hubmaier se koristi riječju kirchgenossen kojom označava župljane ili članove Crkve. No ona ne uključuje smo formalnu pripadnost već aktivno sudjelovanje vjernika sa svim dužnostima i odgovornošću, što se uvelike razlikovalo od koncepcije pasivnih župljana. Vjernik je bio suodgovoran za svoju braću u Kristu na aktivan način. Trebao se brinuti o tome da svatko ima što jesti, obući i da ima zaštitu društva u kojem se nalazio. To je posebno vrijedilo za one koji su bili „izloženi jasnoj, čistoj i nepromjenjivoj Riječi Božjoj“ (Pipkin i Yoder 1989, 33-34). Za sliku brbljivaca snova, aludira na svetopisamski tekst iz Jr 23,25-32.

U 14. tezi, govoreći o čistilištu, Hubmaier smatra kako je pozadina te doktrine temeljena na bogaćenju svećenika. Kaže da: „oni koji traže čistilište, vjeruju u one čije dobro je njihov trbuh, traže grob Mojsija, koji nikada neće pronaći."Kao što je poznato iz Staroga zavjeta, ne zna se mjesto Mojsijeva groba. Hubmaier, 
pišući ovu tezu, aludira na svetopisamski tekst iz Fil 3,19 i Pnz 34,6. Kao što se ne može pronaći njegov grob, ne može se pronaći ni čistilište te se njime koriste za bogaćenje oni koji bi trebali propovijedati Riječ Božju.

15. teza govori o celibatu, ali iz jedne nove perspektive u odnosu na tadašnje prilike. Kada govori o celibatu, Hubmaier gleda na njega kao na nešto nepraktično i neprirodno. Hubmaier interpretira literarni tekst pomoću slikovnih izraza. Uspoređuje zabranu svećeničke ženidbe i toleriranje s podsmijehom njihove tjelesne raspuštenosti, bijede i nemorala, s oslobađanjem lopova i razbojnika Barabe od kazne, a ubijanjem nedužnog Krista.

U 16. tezi još se jednom osvrće na moralnu čistoću. Držanje celibata u ljudskoj snazi nije moguće. Ono je poput letenja, ali bez krila, preko velikih morskih prostranstava.

17. teza potiče vjernike da se opredijele za istinu i pravdu. Ne može se zauzeti neutralni položaj. Hubmaier osuđuje potplaćenu šutnju ili prešućivanje istina koje jasno stoje u Svetome pismu. Takvi će biti odbijeni od Krista, poput Ezava koji je bio prvorođenac i mogao primiti Očev blagoslov, ali ga je prodao.

U 18. tezi potiče radnu etiku u skladu sa Svetim pismom iz knjige Postanka. Svi oni koji na lak način žele doći do svoga kruha svagdašnjeg nisu dostojni hrane koju jedu.

Na samome kraju, Hubmaier završava teze poznatim izrazom: Die warhet ist untödlich. Ovaj bi se izraz mogao trojako prevesti. Kao istina je besmrtna, istina je nevidljiva ili istina je neuništiva. Za ispravno tumačenje ove Hubmaierove izreke, potrebno je uzeti u obzir sva tri značenja.

Hubmaier je nakon objave svojih teza, odmah krenuo u njihovu primjenu. Do kraja godine iz Crkve je izbacio slike i kipove. U pismu svome prijatelju piše da se Krist prvi put nastanio u njegovu životu (Estep 1986, 51). Ta je promjena rezultirala hrabrim svjedočanstvom i odlučnim širenjem Evanđelja.

\section{Zaključak}

Balthasar Hubmaier bio je vodeći intelektualac na početku anabaptističkog pokreta te je dao velik doprinos razvoju toga krila reformacije. Kada su anabaptiste proganjali, oni su bježali iz svoga švicarskog središta prema Češkoj i Nizozemskoj, da bi kasnije spas pronašli u „novom svijetu“. Iskra anabaptizma, koja se zapalila u srcu Europe, nakon mnogo stoljeća ponovno će buknuti u Europi i širom svijeta. Današnje crkve reformacijske baštine nastale su na zasadama ranog anabaptizma, a uključene su u evanđeoski pokret koji čine najbrže rastuće kršćanske crkve u svijetu.

Ovo kratko djelo, koje sadrži svega 18 teza, predstavlja Hubmaierovu težnju da potakne vjernike na nužnost povratka na izvor - ad fontes. Taj je izvor Božja 
Riječ na kojoj je Hubmaier gradio svoj cjelokupni kršćanski život. Riječ je bila i ostala temelj reforme Crkve i pokretačka snaga promjena u skladu s Božjim zapovijedima.

Hubmaierova poznata izreka bila je: Istina je besmrtna. ${ }^{5} \mathrm{Ta}$ istina jest sam Krist. Isus je istina, put i život. Za tu istinu je Hubmaier živio, za nju je umro, ali po njoj ima i besmrtni, vječni život sa svojim spasiteljem kojega je slijedio do smrti.

Njegovih 18 teza već gotovo pola tisućljeća stoje poput smjerokaza za kršćane širom svijeta.

\section{Literatura}

Armour, Rollin S. 1966. Anabaptist Baptism: A Representative Study. Scottdale. Herald Press.

Bergsten, Torsen. 1978. Balthasar Hubmaier: Anabaptist Theologian and Martyr. Valley Forge. PA Judson.

Broadbent, E. H. 1989. Jedna povijest crkve. Zagreb. KC Betanija.

Bender, S. Harold. 1944. The Anabaptist Vision. Herold Press.

Chatfield, Graeme Ross. 1993. "Balthasar Hubmaier and the clarity of Scripture." Doktorska disertacija. University of Bristol.

Chatfield, Graeme Ross. 2013. Balthasar Hubmaier and the Clarity of Scripture. Eugene. Pickwick Publication.

EatonToward, Matthew. 2010. An Anabaptist Covenantal Soteriology: A Dialogue with Balthasar Hubmaier and Contemporary Pauline Scholarship, Mennonite Quarterly Review 84, no. 1. 67-93.

Estep, W. R. 1986. Istina je neuništiva. Novi sad. Dobra vest.

Graffagnino J. Jason. 2017. Balthasar Hubmaier: The Theologian of The Anabaptist, Nikolsburg and Catechetical Instruction: A Labor of Love. Perichoresis Volume 15. Issue 4. 13-32.

Hubmaier, Balthasar, 1524. Achtzehen schluß rede so betreffende ein gantz Cristlich leben, waran es gelegen ist. Augsburg Ramminger/Staats- und Stadtbibliothek. https://books.google.hr/books/about/Achtzehen_ schlu\%C3\%9F_rede_so_betreffende_ei.html?id=4pYFmdRCd1YC\&redir_ esc $=y$ (pristupljano 18.02.2018).

5 Više o ovoj temi, vidjeti u: Klager, P. Andrew. „Truth is Immortal“: Balthasar Hubmaier (c.14801528) and the Church Fathers, doktorska disertacija, University of Glasgow, 2011. 
Jambrek, Stanko. 2011. O anabaptističkoj tradiciji reformacije i Schleitheimskom vjeroispovijedanju. Kairos: Evanđeoski teološki časopis 2/2011. 342343.

Klager, P. Andrew. 2011. "Truth is Immortal: Balthasar Hubmaier (c.1480-1528) and the Church Fathers". Doktorska disertacija. University of Glasgow.

Lansen, Andreas. Schlussreden. http://glaubensstimme.de/doku.php?id=autore n:h:hubmaier:schlussreden. ( pristupljno 15.02.2018).

MacGregor, Kirk R. 2006. The Sacramental Theology of Balthasar Hubmaier. Lanham. University Press of America.

McGreath, Alister E. 2001. Christian Theology. Maden. Blackwell.

Matošević, Lidija. 2007. Rasprava o krštenju između Luthera i Anabaptista promatrana u kontekstu srednjovjekovne teologije. Bogoslovska smotra 77, br $1,121-155$.

Nordenhaugh, J. 1969. Umro je za slobodu vjere. Glasnik baptističkih crkava u SFRJ, broj 5 (17) godina II, 65-66.

Pipkin, H. Wayne i Yoder, John. Howard. 1989. Balthasar Hubmaier, Theologian of Anabaptism. Scottdale. Herald Press.

Smithson, R. 1935. The Anabaptists: Their Contribution to our Protestant Heritage. London. James Clarce and Co.

Snyder, C. Arnold. 2009. Povijest i teologija anabaptizma. Zagreb. TFMVI.

Vedder, Henry. 1905. Balthasar Hubmeier, the leader of Anabaptists. London. Putnam's Sons.

Wiens, Rudolph Henry. 2010. "Balthasar Hubmaier’s Sword: A Circumstantial Development.” Magistarski rad. University of Waterloo.

Westin, Gunnar i Torsten Bergsten. 1962. Quellen zur Geschichte der Täufer IX, Hubmaier, Balthasar: Schriften, Quellen und Forschungen zur Reformationsgeschichte. Gütersloh. Gerd Mohn.

Whitlock, Michael. 2014. Balthasar Hubmaier's Doctrine of Justification. Southwestern Journal of Theology. Volume 56. Number 2, 147.

Williamson, T. Daren. 2005. "Erasmus of Rotterdam's Influence upon Anabaptism: The Case of Balthasar Hubmaier." Doktorska disertacija. Simon Fraser University.

Yoder, J. H. 1959. Balthasar Hubmaier and the Beginnings of Swiss Anabaptist. $M Q R$ 33. 5- 17. 
Danijel Časni

\title{
Balthasar Hubmaier and His Eighteen Articles
}

\begin{abstract}
The paper talks about the renowned Anabaptist reformer, Balthasar Hubmaier, whose works were a significant contribution to the development of the early Anabaptist movement. In 2018 we mark the 490th anniversary of his death of being burned at the stake for his religious beliefs. In the paper, we see an outline of Hubmaier's biography and an overview of his creative work. Special attention is given to his first work from June 1524, which contains 18 articles, and is called, "Achtzehn schluß rede so betreffende ein gantz Cristlich leben." The articles show Hubmaier's view on theology, ecclesiology, and pastorology at the beginning of his reformation work.
\end{abstract}

